\title{
State-Owned Jute Mills in Bangladesh: Problems and Possible Way-Out
}

\author{
Mohammad Mobarak Hossain ${ }^{1} \&$ Nasrin Sultana Nishu ${ }^{2}$ \\ ${ }^{1}$ Lecturer, Department of International Business, Faculty of Business Studies, University of Dhaka, Bangladesh \\ ${ }^{2}$ Freelance Researcher, MBA, Department of International Business, University of Dhaka, Bangladesh \\ Correspondence: Mohammad Mobarak Hossain, Lecturer, Department of International Business, Faculty of \\ Business Studies, University of Dhaka, Bangladesh. E-mail: mobarak.ib@du.ac.bd
}

Received: December 26, 2020

Accepted: Feburary 13, 2021

Online Published: March 11, 2021

doi:10.5539/ijbm.v16n4p63

URL: https://doi.org/10.5539/ijbm.v16n4p63

\begin{abstract}
Historically, jute is known as the golden fibre of Bangladesh, a leading cash crop and major export item for Bangladesh. Unfortunately, the production and export of jute have been declining since the 1970s due to the various internal and external problems. The Bangladesh government has recently declared to shut down the production at all state-owned jute mills. This paper aims to determine the reasons behind the state-owned jute mills failure and feasible solutions to unravel the problems. An in-depth interview with 10 (ten) industry experts was conducted to collect primary data. Secondary information has been collected from different books, websites, articles and newspapers. The demand for various and versatile jute products has been increasing globally over the last two decades. Still, in Bangladesh, the jute sector's development is no longer satisfactory to retain its glorious position towards the world because of having some major problems such as mismanagement and corruption of BJMC, lack of modern machinery, lack of skilled workers, weak marketing and government policies etc. Most state-owned jute mills under BJMC are stuck in dishonesty and lavishness alongside ageing infrastructure. They have been incurring losses for years, turning profits in just four of the last 48 years. Reform and restructuring of $\mathrm{BJMC}$, modernizing factory with the latest technology, providing enough training to employees, investment in research work, improvement in the production process, efficient marketing strategy and appropriate government policies might help the state-owned jute mills to regain its position in the national and international market. There are no reasons to shut down the production where reformation is adequate to make the state-owned jute mills profitable. At least, the time to shut down state-owned jute mills is not right due to the Coronavirus pandemic.
\end{abstract}

Keywords: Jute, Golden Fibre, State-owned Jute Mills, Bangladesh Jute Mills Corporation (BJMC)

\section{Introduction}

Jute is popularly known as the golden fibre of Bangladesh, which is one of the cheapest and the strongest natural fibre. Though contribution to the economy has been reduced after independence, still, jute is playing a vital role in shaping the economy of Bangladesh. Bangladesh earns a significant foreign currency by exporting raw jute and jute goods worldwide. Subsequently, jute has become the industrial material for the production of packaging materials. Bangladesh had been the single largest exporter of jute fibre until 1960, and the country's share of world exports varied from 90-95\% (Rahman and Khaled, 2011). It had been sharing a large portion of GDP earnings of Bangladesh. Before the 70s till the readymade garments appeared, Bangladesh earned a fabulous foreign currency from jute. Bangladesh exports mainly yarn, twine, sacks and bags (Textile Today, 2017). The quality of jute of Bangladesh is far better than any other country in the world. The export of jute and jute-made goods have been increased by 21.55 per cent in the first half (July-December) despite having several problems in the jute industry fetching $\$ 511.73$ million higher than the strategic export target of $\$ 400.72$ million for the period, reports BSS (The Financial Express, 2020). Bangladesh and India together produce 84\% of world production of jute fibre. In recent time, people have become more cautious about the environment, and jute is undoubtedly an environment-friendly product. So, people are now more interested in using jute goods, resulting in more potentiality to earn more foreign currency by selling jute goods in the foreign market. According to a recent report, global jute market revenue was US $\$ 2.7$ billion in 2018 and projected to going up by $4.6 \%$ against the previous year. The market value has been increased at an average annual rate of $+1.4 \%$ from 2007 to 2018 
(IndexBox, 2019). Apart from that, the global car industry needs about 100,000 tones of jute each year. Bangladesh already supplied 12,000 tones of its best quality jute to world-leading car brands like BMW, Mercedes-Bens, Toyota, Renault, Mitsubishi, Volvo, Audi, Daimler and Ford. With the quality of Bangladeshi jute, Bangladesh can become the main supplier of the jute required for the global car industry and the chance to capture a large portion of the world car market's demand (Mridha, 2018). But it is a matter of sorrow that our state-owned jute mills' authority does not express their urge towards this type of opportunity. Bangladesh government has established Bangladesh Jute Mills Corporation (BJMC) that owns and manage all state-owned jute mills. Earlier, jute was the main cash crop and source of foreign currency for Bangladesh. Now, BJMC is incurring a huge amount of loss every year. Raw jute exporting is a source of revenue for a long time. But raw jute export was stopped respectively in 1984, 2009 and 2015. Moreover, the export was hampered highly in 2013-2014 due to the political unrest. With given loss situation, Bangladesh government is considering shutting down several state-owned jute mills in recent days, and the future prosperity of this industry is in a vulnerable condition. Some of the causes behind these trouble situations are mismanagement and malpractice of BJMC officials, weak market policies, inappropriate government policies, old machinery used in jute mills, constant desire for subsidies and increased cost of production, lack of foresight, corruption of BJMC, and random closures of mills (Islam and Ali, 2018). The government, BJMC, jute mills owners and responsible authority should pay attention to disclose the problems and find out the solutions by considering the importance of this sector from an agricultural, economic, industrial and commercial perspective. In a report of The Financial Express (2020) stated that mismanagement, corruption, and irregularities are to be blamed for loss at state-owned jute mills.

According to the Export Promotion Bureau (EPB), Bangladesh export earnings from jute and jute goods fell to $\$ 816.27$ million from $\$ 1.02$ billion in the last fiscal year (FY2019) (Dhaka Tribune, 2019). And BJMC losses 466.22 crore taka in 2018, and the loss rate is getting higher every year (Parvez, 2019). There are many reasons for this downward trend in the last fiscal year: mismanagement and malpractice in BJMC's mills, corruption of BJMC, weak government and market policies, desire for subsidies, and increased production cost, random closures of mills, and dissatisfaction arise among labours. Since independence, jute has been considered a blessing for uplifting Bangladesh's economic situation. This sector contributes a lot to the employment generation (Islam \& Ali, 2018). As this sector is economically important for our country, any problem this sector faces should be studied and removed as soon as possible. The study is covered in a specified area to talk over the prime reasons for state-owned jute mills failures with sorting out the exhaustive solutions. For unravelling the problem, this study is concluded with effective suggestions for the government and responsible authority for protecting and uplifting the jute industry towards the world.

The government of Bangladesh has declared to shut down the production at all state-owned jute mills (The Financial Express, 2020). When reformation is enough to make those state-owned jute mills profitable, there is no reason to shut down the mills. The total contribution of jute is enormous. Jute is significant for agricultural production, economic, industrial and commercial. After cotton, globally, jute is the second most vital vegetable fibre in terms of usages, production and availability. The contribution from Jute to nation's GDP has been declined after the independence of Bangladesh. But still, it plays a significant role. It is noticeable that jute becomes the second position in export trade replacing leather industry in 2020 (Dhaka Tribune, 2020). So, a study is required to determine the real scenario of Bangladesh's jute industry and find out the possible way out so that responsible authority can rethink their decision to shut down the production at all state-owned jute mills. If the analysis is not done, there might be missed opportunities and problematic loopholes which need to be covered to become more competitive in the jute sector. In this study, the problems faced by the state-owned jute mills have been discussed, and some possible way-out has been proposed for the government and the responsible authority.

\section{Literature Review}

Though contribution from jute has been declined over the years for several internal and external reasons, still, it plays a more significant role in employment generation (Mahmud, 2020). It is noticeable that jute comes in the second position in the export trade of 2020 (Dhaka Tribune, 2020). Bangladesh government should take appropriate policies to make the state-owned jute sector to gain its lost glory. The current status of jute as a cash crop is not satisfactory at all though the economic importance of jute is enormous (Islam \& Ali, 2017).

"Industrial Research Advances of Jute in Bangladesh (2018)" by Md. Mahbubul Islam and Md. Saheb Ali provided information about the important features of jute, the chemical composition of jute fibre of Bangladesh. Several workers related issues in the jute sector and production of jute are also discussed in this article. By not having modern machinery and sound technologies, the state-owned jute mills of Bangladesh incur an 
unnecessary cost which in turns increase the cost of production and maintenance (Moazzem et al., 2009). Bangladesh government is trying to close down the state-owned jute mills by considering various stakeholders and civil society organizations concerning the economic judgement (Moazzem et al., 2009). Zahirul Hoque and Trevor Hopper (1994) discussed the management system of Bangladeshi jute mills. The authors point out some challenges regarding the management system of the jute mills. Mismanagement and corruption make it more difficult to survive today's world's economy. Especially in state-owned jute mills, these problems become more acute. Zahirul Hoque and Trevor Hoppers (1997) stated that the political practices of Bangladesh create obstacles for the jute industry in Bangladesh in many ways. BJMC is responsible for state-owned jute mills failure. Falling of export volume due to the global market demand and the anti-dumping duty imposed by India, inadequate local sales, purchasing jute at a higher price and selling below production cost by BJMC, lack of good professional in the top management of BJMC, corruption, inefficiency, backdated technology, presence of ghost workers, and lack of competitive zeal in BJMC are some reasons behind state-owned jute mills failure (Parvez, 2019). In a personal interview with Dhaka Tribune, CEO of the Business Initiative Leading Development (BUILD) Ferdaus Ara Begum pointed out that corruption and mismanagement are the root cause for the failure of BJMC (Mahmud, 2020). According to a report published by The Daily Star (Tithi, 2019), bad management, old technology, poor planning, corruption and lack of government initiatives are the reasons why state-owned jute mills failed to stand on its own feet. There is a common belief that bad management, lack of product diversity, corruption and planned marketing are reasons for state-run jute mills failure. Hence, the blame is placed squarely on the BJMC (Ahmed, 2020; Harmachi, 2020).

Another perspective has been discovered on what has been affecting the production of jute. Md. Mahbubul Islam (2014) revealed that the cost of weeding along comes from $30 \%$ to $40 \%$ or even more of the total cost of jute cultivation. Jute weeds indirectly reduce the quality and quantity of fibre. Increasing competitiveness in the world market also affects the export competitiveness of the jute of Bangladesh. Mostafizur Rahman and Nafisa Khaled (2011) discussed the global trend towards the jute industry and the performance of Bangladesh in the jute industry. One of the main problems for jute cultivation is lack of sufficient amount of good quality water during harvesting time (May-June) due to the irregularity in monsoon (Sarkar \& Sengupta, 2015). In most of the top jute producing countries, a shortage of supply has increased the price of the raw jute (Shehli \& Roy, 2014). Jute Diversification Promotion Center (JDPC) developed a list consisting of 232 diversified jute products. These diversified products are generally exported to other countries and earn huge foreign currency. The website of Finance Ministry of Bangladesh, Bangladesh Jute Association, and Bangladesh Jute Mills Corporation regularly published and updated data regarding financing to jute industry, export-import data, harvesting jute area, amount of jute production etc. Food and Agriculture Organization also published data regarding the jute production of Bangladesh. Gupta et al. (2009) found that countries that have treated jute as one of the predominant cash crops were having a tremendous impact on the economic growth of these agriculture-based countries.

Jute has become one of the important sources of earning foreign currency for Bangladesh. Opportunities and challenges are equally existing in the world market. Bangladeshi policymakers and the owners of jute mills should take necessary steps to grab the opportunities and reduce the challenges (Chowdhury \& Rashed, 2015). Jute is an environmentally friendly element. And in today's world, people have become more conscious about the environment. This tendency leads to an opportunity for the jute to earn huge amount of profit by selling and exporting raw jute and jute products (Islam \& Ahmed, 2012). Mismanagement in BJMC, inappropriate buying process, corruption, fund shortage makes it impossible to survive the public jute sector of Bangladesh (The Financial Express, 2018). An industrial article that is retrieved from The Daily star titled 'BJMC burdened with losses' (2019) showed the worst situation of Bangladesh Jute Mill Corporation. How the corrupted officials turn the organization into a profitless organization is discussed throughout the article. The low price of raw jute frustrates the farmers of Bangladesh. The middleman, in this case, made the situation even worse and deprived the farmers of their gain.

An industrial article regarding the low price of jute focused on Munshiganj's farmers published in Dhaka Tribune (Hasan, 2019). In 2010, Bangladesh's government made a law regarding jute packaging in certain product items. In 2015, 15 products were listed for which jute packaging was mandatory. An article about the government's role in promoting jute bags retrained from The Daily Star (Parvez, 2018). Another report also published on UNB news regarding the use of jute bags. In 2018, the government decided to make it mandatory to use jute packaging for poultry and fish feeds. The article focused on the government's decision and the poultry farm owner's responses and fish feed mills owner to the decisions (Dhaka Tribune, 2018).

Advance technology and skilled workforce are the keys to ensure efficiency and productivity in state-owned jute mills. Good collaboration among the stakeholders is required to revive the industry. Improved product quality 
might help to fight anti-dumping duties imposed by different countries. The government should take research outcomes for converting theories into reality (The Financial Express, 2018). There are no state-owned jute mills in India, but the government has ensured an environment, where privately owned jute mills can run efficiently. Suppose the government wants to shut down state-owned jute mills and start again under PPP. In that case, it must ensure policy supports like strengthening concerned institutions and increasing better warehouse capacity (Mahmud, 2020). Bangladesh needs investment to stir up the innovation so that jute goods diversification may occur, and old machinery needs to be modernized to improve productivity. Currently, BJMC mills are operating below 50 per cent efficiency level. Reduction of corruption and mismanagement in buying raw jute by BJMC could make the state-owned jute mills profitable. BJMC needs to buy raw jute at the peak of the harvesting season, which is July, and BJMC should buy raw jute from farmers instead of shippers and hoarders (Nithi, 2019). In this research paper, researchers tried to dig up State-owned jute mills' main problems with practical solutions to unravel the difficulties to regain the past glory of the jute industry in Bangladesh.

\section{Methodology}

The paper's main research objective was to identify the problems faced by the state-owned jute mills in Bangladesh and suggest possible way-out. This paper aimed to know why the golden days of jute fibre have gone. This study is based on primary and secondary sources. While searching for secondary data, an extensive literature review has been made to identify the problems faced by state-owned jute mills for a long time and proposed solutions. Secondary data have been collected from the annual reports of Jute mills, books, articles, newspaper and different websites of authorities or organizations associated with Jute data such as BJMC, BJRI, JDPC, International Jute Study Group, Food and Agriculture Organization statistics. Apart from secondary data, this study also used primary data. An in-depth interview was conducted with ten experts working in this industry for at least ten years for collecting primary data. Their responses have been aligned with the secondary data collected from various sources.

\section{Discussion}

The information presented here comes from an extensive literature review and the direct interview. The researchers have decided not to present each interview question outcome as researchers don't want to confuse readers by providing too much information. In this part of the research paper, researchers discussed major impediments to state-owned jute mills success which is also the root cause for state-owned jute mills failure.

\subsection{Major Impediments to State-Owned Jute Mills of Bangladesh}

\subsubsection{Mismanagement and Malpractice of State-Owned Jute Mills}

Having no adequate policies and legal provisions on jute, a haphazard situation occurs in this sector today. There is no consistency in case of management of state-owned jute mills. In general, project heads are responsible for operating public jute mills. Jute board is the proper authority to oversee a jute mill's operation, but they have limitations to make the decisions in practice. It is indeed the jute board's responsibility to make decisions regarding the procurement of raw jute, recruitment of workers, distribution of jobs, fixations of wages levels etc. Still, they can't make decisions due to some unknown limitations (Islam and Ali, 2018). Whether strategic, marketing, financial or policy-related, most of the essential decisions are made by the BJMC. Moreover, the decisions made by BJMC regarding the procurement of raw jute, maintenance of types of machinery and workers found to be time-consuming and troublesome. Since BJMC has the authority to make decisions on many crucial public jute mills issues, it would need to be more responsible.

According to the respondents of this study, since 1980s BJMC has suffered from some acute problems. One of the main problems of BJMC's poor performance is the lack of experienced top management officials. Bangladesh Jute Mills Corporation (BJMC) arbitrarily fix jute price, wage scale, remuneration, etc. Due to the government's lack of attention on the public jute mills, various types of mismanagement and malpractice have been done by the public jute mills. Of them, one is that jute is procured at a higher price apart from the jute harvesting season. Instead of buying raw jute during the peak harvesting season in July when one mound of jute sells at Tk. 1,000 to Tk. 1,200 the corporation (BJMC) always tends to buy raw jute in the offseason at Tk. 2,000 to TK 2,200 (Tithi, 2019). Also, they buy from shippers and hoarders, not directly from farmers which indicates hundreds of crore taka is wasted in simply purchasing raw jute resulting from inefficiency and mismanagement of BJMC officials. The management practice of BJMC become more inefficient day by day (Parvez, 2019). According to CPD, BJMC mills are only $50 \%$ efficient currently. The inefficient management practice of BJMC destroy this profitable sector of Bangladesh economy and incurs loss every financial year. 


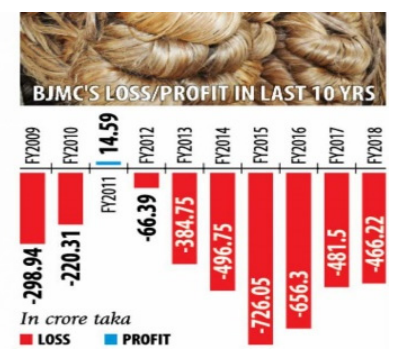

Figure 1. BJMC's Loss/Profit in the last 10 years

Source: (Parvej, 2019).

\subsubsection{Outdated Technology}

Cost of production in jute mills has been increased over the years due to outdated technology. The jute industry's comprehensive technology did not change much over the years, which should not be the case. Lack of modern technology brings fall in the final demand of the products (Moazzem et al., 2009). And these outdated technologies incur an unnecessary cost, resulting in a higher production cost. Currently, 4452 mills out of 10835 under the BJMC are in operation (Parvez, 2019). According to this study's respondents, productivity is falling in the running mills due to old machinery and technology. Maintenance of these ancient technologies also incurs higher cost. Our jute industry's revival and growth are hardly possible without sound technologies and modern machinery. According to a report of The Daily Star, most of the jute mills of Chittagong have lost their 40-50 per cent production capacity due to the absence of modern machinery and maintenance of the existing one. There are many scopes to increase the running jute mills' production capacity. But having old machinery creates obstacles to use the chance to boost production. According to the expert's panel, the machinery's longevity is 30 to 40 years (Chakraborty, 2012). After independence, no BMRE (Balancing, Modernization, Rehabilitation and Expansion) was done. In the face-to-face interview, experts stated that only BDT 5000 crore would be enough to modernize all jute mills under the BJMC.

\subsubsection{Low Productivity}

According to the expert's panel, the low productivity in state-owned jute mills is a big problem. It is estimated in a survey that more than 90 workers are required to produce one ton of sacking whereas the private sector can do the same by approximately 25 workers. And job specialization is not practiced by the works of a different section of state-owned jute mills. In carding, drawing, spinning, and weaving, the man-machine ratio is more homogeneous (Moazzem et al., 2009). Having a lack of skilled and qualified labours, the state-owned jute mills have utterly failed to cope with the changing situation. Female workers are mostly found in less skilled oriented works which also seems to be a productivity problem.

\subsubsection{Higher Production Cost}

According to the respondents, the jute fibre production cost is higher than the selling price. As in state-owned jute mills, outdated technologies and traditional machinery are used, so the higher cost is incurred in production. Low productivity of labours and machine increases the production cost in state-owned jute mills. Payment to ghost workers also raises the operating cost. BJMC's officials were buying raw jute from the intermediaries at a higher price instead of following the appropriate process of buying raw jute directly from the farmers at a lower price. This also increases the production cost (Parvez, 2019). The inefficiency of their management also responsible for this situation. All these factors together are the reasons for the higher production cost.

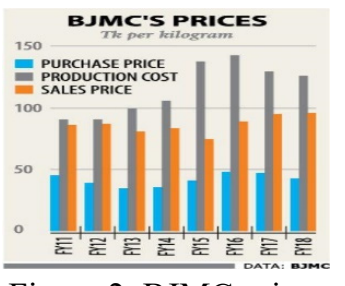

Figure 2. BJMC prices

Source: (Parvez, 2019) 


\subsubsection{Corruption of Bangladesh Jute Mills Corporation (BJMC)}

BJMC is the authority of state-owned jute mills. According to respondents, unskilled management has turned the jute sector into a corrupt hub. Their corruption has spread out from workforce recruitment to buying raw jute. It can be easily said that the corrupted officials of BJMC make it impossible to run the jute industry profitably and regain the lost glory of our golden fibre. In buying raw jute, BJMC always tends to buy raw jute in the offseason while the price is higher than the regular price. And they also do not follow the appropriate buying process. Instead of buying directly from the farmers, they buy low-quality raw jute from the hoarders and shippers (Parvez, 2019). And by doing this continuously, they incur a loss of crore taka in merely buying raw jute, which results in jute mills cutting production by around 66 per cent. In the recruitment process, corruption becomes more acute. For example, in 2011, while the government decided to reopen five jute mills, many irregularities in the recruitment process existed there. In that time government provided Tk. 1.05 billion and recruited 35,000 workers, among which 22,520 were without any work experience (Abedin, 2019). According to Prime Minister Sheikh Hasina, BJMC is an 'autistic child' of the nation. The government will give special attention to Bangladesh Jute Mills Corporation, said the State Minister for Jute and Textiles, Mirza Azam (The Daily Observer, 2017).

\subsubsection{Shortage of Funds}

BJMC has received Tk. 7,477 crore to bail out its financial crisis over the last ten years, yet it needs more. This is very unfortunate that BJMC officials demand more fund (Tithi 2019). Fund shortage is another problem found in state-owned jute mills, said by experts' panel. Funds are not available in time. State-owned jute mills have lost their creditworthiness due to the default of past debts. Most state-owned jute mills are overburdened with debt and interest charges associated with these debts. Also, Bangladesh Jute Mills Corporation claims that they do not get their allocation in time. Due to cash problem, BJMC jute mills have been failing to buy raw jute from farmers at the harvest time, and it has resulted in jute mills cutting production by around 66 per cent. Due to the lack of raw jute, 1914 handlooms in nine nationalized jute factories across Khulna and Jessore shut down. In December 2018, BJMC sought Tk. 420 crore from the government but received only around 80 crores while the corporation already owes raw jute traders Tk. 420 crore (Molla, 2019). According to the respondents, the delay in purchasing raw jute forces factories to incur more losses. This situation is also the result of the inefficient and unskilled management system of BJMC.

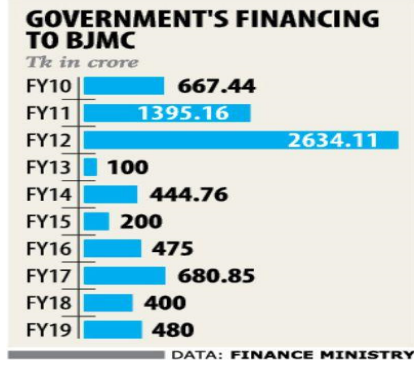

Figure 3. Government's Financing to BJMC

Source: (Parvej, 2019).

\subsubsection{Poor Quality of Raw jute and Seeds}

The quality of raw jute of Bangladesh is the finest worldwide. According to the respondents, nowadays due to the mismanagement in the cultivation process, lack of training and insufficient machinery, the raw jute quality decreases. Farmers of Bangladesh conventionally grow seeds and fibre simultaneously from the same plants which in turns caused hampers to the quality of seeds and fibre. Lack of good quality free-flowing mild water is one of the main problems in jute cultivation (Sarker and Sengupta, 2015). Some of the factors that lead to the low quality of jute fibre which in latter used in public jute mills are lack of retting water, high disease infestation, lack of training facility, lack of quality seeds, high cost of the production process, inadequate credit facilities, high price of inputs, unstable jute price, shortage of labour and weed problem (Sheheli and Roy, 2014).

\subsubsection{Random Closures of Mills}

According to experts' panel, mills' random closures create an obstacle for the industry's development. Due to the mismanagement and shortage of funds in the jute industry, more than 63 jute mills out of 314 have been closed from Bangladesh's independence year. Among them, seven public jute mills out of 33 and 56 private jute mills 
out of 281 have been closed (Bangladesh Gazette, 18-19). India is imposing anti-dumping duties on the export of jute goods from Bangladesh. In 2002, Adamjee Jute Mill was announced to be closed on 30 June 2002 (Hoque and Trooper, 1997). Adamjee Jute Mill was the biggest jute mill in Bangladesh and the establishment covered 300 acres of land. After that, seven jute mills among 33 public jute mills and 56 jute mills out of 281 private jute mills have been closed. This random closure of jute mills creates obstacles in many ways that affect the jute industry of Bangladesh (Islam and Ali, 2018).

\subsubsection{Dissatisfaction Arise among Workers}

Unfortunately, state-owned jute mills often do not get their wages in time. Till, 2017, BJMC owed Tk. 387 crore to the workers and officials who have been retired or died in service since July 2013. In 2015, the Government of Bangladesh announced a new pay scale that BJMC has not implemented. As a result, workers get dissatisfied. Due to their dissatisfaction, they often strike and close the mills to fulfil their demands. It creates violence and instability in the jute industry. And it also deteriorates the reputation of Bangladesh's jute industry towards the world. Recently, the workers of state-owned jute mills have gone on a strike, demanding complete and unconditional payment of their arrear wages (Hasan, 2019). As they shout down the mills, the production of jute product hampers and state incurs a loss. Jute mills lost Tk 4.81 billion during 2016-17 (Parvez, 2019). According to the experts' panel, the inconsistent payment system of wages causes this difficult situation, and they blame the in-efficient finance management and human resource management of BJMC.

\subsubsection{Inadequate Investment in Jute Sector}

In Bangladesh, more than 50 spinning mills use viscose fibre worth about TK. 700 to 800 crore. Bangladesh needs to import viscose fibre (Textile Today, 2017). If Bangladesh can produce this fibre, it will be considered an import substitution, reducing foreign currency outflow. Bangladesh needs to diversify jute goods and expand the market, demanding more investment for the sector. Jute diversification requires investment. Jute Diversification and Promotion Center and Bangladesh Jute Research Institute need investment to develop the new ideas. These two institutions are suffering from several problems. Some of these are lack of investment, lack of workforce, lack of laboratory facilities, lack of training etc. (Moazzem and Chowdhury, 2010). According to the respondents, a large investment is needed to produce quality full and diversified jute products in the jute sector.

\subsection{Summary}

Jute is the second top export items for Bangladesh as of $31^{\text {st }}$ May 2020 with a total earning of US\$ 791.3 million in ten months of the current fiscal year (The Financial Express, 2020). Analyzing the jute sector of Bangladesh, there are many reasons behind the failure of the government to protect and uplift the jute industry towards the world such as mismanagement and malpractice of public jute mills, outdated technology, low productivity, corruption of BJMC, shortage of fund, low quality of raw jute and seeds, random closures of mills, and less investment in jute sector etc. The public sector could not keep its feet with the private sector due to these problems. Hence, the public sector is lagged. These problems would be the catalyst to debar the public sector from flouring jute industry. The government, along with the BJMC, BJMA, JDPC and BJRI should have the prime concern to determine these very root problems in public jute mills. For regaining the lost glory of the jute sector towards the world, these problems should be removed permanently.

Table 1. Ranking the problems according to the experts' panel

\begin{tabular}{lll}
\hline SL & Problems & Mean Score* \\
\hline 1 & Corruption of Bangladesh Jute Mills Corporation (BJMC) & 4.9 \\
2 & Mismanagement and Malpractice of Public Jute Mills & 4.8 \\
3 & Outdated Technology & 4.7 \\
4 & Inadequate Investment in Jute Sector & 4.6 \\
5 & Low Productivity & 4.5 \\
6 & Dissatisfaction Arise Among Workers & 4.5 \\
7 & Shortage of Funds & 4.4 \\
8 & Higher Production Cost & 4.3 \\
9 & Random closures of mills & 4.3 \\
10 & Poor Quality of Raw jute and Seeds & 4 \\
\hline
\end{tabular}

Note. $* 5$ points Likert scale has been used to measure the severity of the problems. $1=$ lowest severity and $5=$ highest severity.

Source: Survey data 


\section{Conclusion and Recommendations}

\subsection{Conclusion}

Keeping pace with the world for setting the jute sector in a proper position, the government and the responsible authorities should put the prime concern to find out the reasons behind the failure. After sorting out the state-owned jute mills' problems, the government should take necessary measures to regain her lost glory in the world market. Shutting down the state-owned jute mills couldn't be the solution at all rather proper steps must be taken to eradicate the identified problems. The reasons behind the state-owned jute mills failures are known to all. Government and responsible authority need to solve those problems rather than kill those state-owned jute mills. Shutting down those jute mills won't bring any good instead it will bring new issues for the country which might be more devastating given pandemic situation. Where reformation is sufficient to make the state-owned jute mills profitable, there are no reasons to shut down. Given Covid-19 situation, the demand for green products will be increased in the global market. So, the government should focus on taking the benefits of the conditions. Taking the benefits, the government must protect the interest of state-owned jute mills.

\subsection{Recommendations}

\subsubsection{Introduction}

To remove problems in the jute industry, it is now a crying need to find appropriate and practical solutions. There are a lot of suggestions given for uplifting the jute industry in the best position such as to reform and restructuring of BJMC, to stop the corruption of BJMC immediately, modernize and to bring a balancing of machinery used to attain a higher level of productivity, bring radical improvement of the production process, ensure research, training, promotion, and awareness-building activities, encourage public-private partnership, develop appropriate and efficient marketing policy etc.

\subsubsection{Reform and Restructuring of Bangladesh Jute Mills Corporation (BJMC)}

Even though the government is of utmost trying to progress and uplift the jute sector in the best position toward the world, many problems are appearing in this sector today. The Bangladesh Jute Mills Corporation's reforming is a crying need to unravel these problems. Without implementing the reformation of BJMC, it would be impossible to go with a better position as we expect from our jute sector. To restructure the BJMC, some action should be performed by the government such as the rationalization of public sector jute mills, rationalizing the number of workers, encouraging PPP, ensuring enough funds for the repayment of all arrears of workers, payment of dues to suppliers, amortization of debt, and improving marketing strategies etc. It's high time to reform and restructure the organization for booming the public jute sector remarkably towards the world.

\subsubsection{Corruption of Bangladesh Jute Mills Corporation Must be Eradicated}

Corruption is like a ball of snow. Once it is set a rolling, it must be increased. One of the main barriers of the jute industry for booming is corruption. There is legislation on it as the Anti-corruption Commission Act, 2004. Due to the lack of implementation of this Act, public jute mills' corruption under BJMC and BJMC is increasing rapidly day by day. For rescuing and uplifting the jute sector, the government should pay proper attention to the implementation of this Act and at the same time, take other necessary policies for the removal of corruption of this organization.

\subsubsection{Modernized and Balancing of Machinery to Achieve Higher Productivity}

Improvement of productivity wouldn't be possible if the existing machinery sets are not changed. In state-owned jute mills, both machine and labour productivities need to be enhanced (Moazzem \& Chowdhury, 2010). Instead of using these machinery types, public jute mills should adopt old kinds of machinery with new types of machinery and modern technologies. The state-owned jute mills need to follow modern production methods and maintenance techniques for attaining the higher level of productivity. The government should allow the public jute mills the appropriate autonomy power to take this action.

\subsubsection{Funds Must be Available in Harvesting Time}

BJMC claims that they do not get their allocation in time. And due to cash problem, BJMC jute mill has been failing to buy raw jute from farmers at the harvest time, and it has resulted in jute mills cutting production by around 66 per cent (Abedin, 2019). The government should ensure that funds are available to the BJMC jute mills during the harvesting time. They can buy raw jute at a cheaper rate, reducing the cost of buying raw jute. And it also helps to buy good quality raw jute. 


\subsubsection{Improvement of the Production Process}

What are the possible solutions to get out of this situation? This question was asked to the experts to know how to solve the problem. According to all of them, they emphasize the improvement of the production process more. The current production process used by the state-owned jute mills is not modern. The production process of public jute mills is not modern. To bring a substantial improvement in jute's overall productivity, both public and private jute mills should give special attention to the production process.

\subsubsection{Research, Training, Promotion, and Awareness-building Activities Must be Performed}

More research for diversifying jute products is required from BJRI, JPDC and other organizations. Unfortunately, BJRI is suffering from several problems: lack of investment, workforce, and training etc. (Moazzem and Chowdhury, 2010). Government and responsible authorities should come forward to help these organizations in this regard. The government and the private jute industry should arrange training program, create awareness-building activities, and create funds for doing comprehensive research on problems and prospects of the jute industry in Bangladesh.

\subsubsection{Improvement of Low-Quality Jute}

The quality of our country's jute is deficient, which in turn affects the marketing of jute products on a global level. This low-quality jute and jute cuttings may be improved by enhancing the growth of microorganisms in the fibre or microbial enzymes' application (Islam and Ali, 2018). Training and modern technologies should be made available to the jute farmers. This helps the farmers to produce good quality raw jute.

\subsubsection{Encouraging Public-Private Partnership (PPP)}

Can Public-Private partnership be a solution to this problem? Most of the experts said that to become more modernized, the public jute mills need more investment, and for this reason, a private-public partnership can be a great way. To operate jute mills, there should be found an alternative way to tackle the challenges faced by these mills in the last couple of years. However, As the State-owned jute mills are on a ramshackle footing, privatization would be an effective way to uproot the problems. The government tries to retain the glory days of public jute industry by adopting assorted projects in the last couple of years. These projects taken by the government cannot be implemented due to the rampant corruption of officers of the BJMC, unconcerned behaviour in the official duty and fragile production plans. Hence, we are deprived of getting success from these projects as well. This sector has been suffering its losses in the last three years. Privatization would be only an effective way to unravel the problem. The reformation of this sector would be possible by bestowing it's to the public sector or private sector or through PPP only if the jute mills' size can be reasonably reduced along with ensuring modern machines. In the case of PPE running, transparency \& accountability should be provided. It must have to a sharp look on a matter in case of conducting the jute mills that there should be no way to take political consideration for its running. To run the jute mills profitably, the first and foremost duty is to take a practical and feasible plan. Modern machines, reducing the workers reasonably, and effective management should be ensured. If these steps can be appropriately handled, the lost glory of golden fibre shall be retained through PPP.

\subsubsection{Develop Appropriate and Efficient Marketing Policies}

BJMC mills mainly focus on low priced market. Global demands for jute products are increasing gradually in the recent year. Bangladesh should change and develop appropriate marketing policies to capture more global market share (Rahman and Khaled, 2011).

\subsubsection{Appropriate Government Policies Must be Developed}

The policies associated with the jute industry need to be reviewed and revised in the context of current business practices. The policy should contain a strategic direction for the long term to remain effective for an extended period. The policy must address the global demand for jute and jute products. 
Table 2. Suggestions that might help the state-owned jute mills to regain its lost glory

\begin{tabular}{lllc}
\hline SL & Problems & Mean Score & Rank \\
\hline 1 & Corruption of Bangladesh Jute Mills Corporation Must be Eradicated & 5 & 1 \\
2 & Reform and Restructuring of Bangladesh Jute Mills Corporation & 5 & 2 \\
3 & Modernized and Balancing of Machinery to achieve higher productivity & 5 & 3 \\
4 & Improvement of the Production Process & 5 & 4 \\
5 & Research, Training, Promotion, and Awareness-building Activities Must be Performed & 4.6 & 5 \\
6 & Develop Appropriate and Efficient Marketing Policies & 4.6 & 6 \\
7 & Appropriate Government Policies Must be Developed & 4.6 & 7 \\
8 & Funds Must be Available in Harvesting Time & 4.5 & 8 \\
9 & Improvement of Low-Quality Jute & 4 & 9 \\
10 & Encouraging Public-Private Partnership (PPP) & 3.2 & 10 \\
\hline
\end{tabular}

Note. $* 5$ points Likert scale has been used to prioritize the suggestions. $1=$ lowest importance and $5=$ Highest importance.

Source: Survey data.

\section{Acknowledgement}

We express our heartfelt gratitude to the interviewee for their valuable time in our interview questions.

\section{References}

Abedin, M. (2019). An Inquest into State-Run Jute Mills’ Downfall. Daily Sun. Retrieved 10 February 2021, from https://www.daily-sun.com/magazine/details/389420/An-Inquest-Into-StateRun-Jute-Mills\%E2\%80\%99-D ownfall

Ahmed, W. (2020). The sad saga of state owned jute mills. The Financial Express. Retrieved 10 February 2021, from https://thefinancialexpress.com.bd/views/the-sad-saga-of-state-owned-jute-mills-1594134408\#: :text=Shutt ing $\% 20$ down $\% 20$ the $\% 20$ state $\% 2$ Drun,due $\% 20$ to $\% 20$ the $\% 20$ ongoing $\% 20$ pandemic

Bangladesh Jute Mills Corporation. (2021). Retrieved 10 February 2021, from http://www.bjmc.gov.bd

Chakraborty, P. (2012). Jute mills run with run-down machinery. The Daily Star. Retrieved 10 February 2021, from https://www.thedailystar.net/news-detail-218917

Chowdhury, I., \& Rashed, M. S. (2015). Market Access of Bangladesh's Jute in the Global Market: Present Status and Future Prospects. Journal of economics and sustainable development, 6, 67-75.

Dhaka Tribune. (2018). Jute packaging made mandatory for poultry, fish feeds. Retrieved 10 February 2021, from https://www.dhakatribune.com/bangladesh/2018/08/12/jute-packaging-made-mandatory-for-poultry-fish-fe eds

Dhaka Tribune. (2019). Earnings from jute, jute goods fall by 20.41\%. Retrieved 10 February 2021, from https://www.dhakatribune.com/business/economy/2019/07/08/earnings-from-jute-jute-goods-fall-by-20-41

Dhaka Tribune. (2020). Jute secures second position in export trade replacing leather industry. Retrieved 10 February 2021, from https://www.dhakatribune.com/business/2020/10/06/jute-secures-second-position-in-export-trade-replacingleather-industry

Dhaka Tribune. (2020). Bangladesh bags $\$ 791.3 \mathrm{~m}$ from jute export in ten months. Retrieved 10 February 2021, from https://www.dhakatribune.com/business/economy/2020/05/31/bangladesh-bags-791-3m-from-jute-export-in -ten-months

Gupta, D., Sahu, P., \& Banerjee, R. (2009). Forecasting Jute Production in Major Contributing Countries in the World. Journal of Natural Fibers, 6(2), 127-137. https://doi.org/10.1080/15440470902931436

Harmachi, A. (2020). Fraying future for farmers as Bangladesh shuts state-owned jute mills. Bdnews24.Com. $\begin{array}{llll}\text { Retrieved } & 10 & \text { February } & \text { 2021, from }\end{array}$ https://bdnews24.com/economy/2020/07/18/fraying-future-for-farmers-as-bangladesh-shuts-state-owned-jut 
e-mills

Hasan, C. (2019). Low jute price frustrates Munshiganj farmers. Dhaka Tribune. Retrieved 10 February 2021, from https://www.dhakatribune.com/business/2019/09/05/low-jute-price-frustrates-munshiganj-farmers

Hoque, Z., \& Hopper, T. (1994). Rationality, accounting and politics: a case study of management control in a Bangladeshi jute mill. Management Accounting Research, 5(1), 5-30. https://doi.org/10.1006/mare.1994.1002

Hoque, Z., \& Hopper, T. (1997). Political and Industrial Relations Turbulence, Competition and Budgeting in the Nationalised Jute Mills of Bangladesh. Accounting And Business Research, 27(2), 125-143. https://doi.org/10.1080/00014788.1997.9729539

IndexBox. (2019). Global Jute Market 2019 - Bangladesh Continues to Dominate Exports, Despite Decline in the Past Few Years. Global Trade. Retrieved 10 February 2021, from https://www.globaltrademag.com/global-jute-market-2019-bangladesh-continues-to-dominate-exports-despi te-decline-in-the-past-few-years/

Islam, M., \& Ali, M. (2017). Economic Importance of Jute in Bangladesh: Production, Research Achievements and Diversification. International Journal Of Economic Theory And Application, 4(6), 45-57. Retrieved 10 February 2021, from http://article.aascit.org/file/pdf/9180778.pdf

Islam, M., \& Ali, M. (2018). Industrial Research Advances of Jute in Bangladesh. International Journal Of Agricultural And Biosystems Engineering, 3(1), 1-9. Retrieved 10 February 2021, from http://www.aascit.org/journal/archive2?journalId=805\&paperId=5820

Islam, M., \& Ahmed, S. (2012). The Impacts of Jute on Environment: An Analytical Review of Bangladesh. Journal of Environment And Earth Science, 2(5). Retrieved 10 February 2021, from https://www.iiste.org/Journals/index.php/JEES/article/view/1999/1978

Islam, M. (2014). Research Advances of Jute Field Weeds in Bangladesh: A Review. ARPN Journal Of Science And Technology, 4(4). Retrieved $10 \quad$ February 2021, from https://citeseerx.ist.psu.edu/viewdoc/download?doi=10.1.1.683.4110\&rep=rep1\&type=pdf

Jute Diversification Promotion Center. (2021). Retrieved 10 February 2021, from http://jdpc.gov.bd/

Mahmud, N. (2020). Jute sector can generate more employment if government provides policy support. Dhaka $\begin{array}{lllll}\text { Tribune. } & \text { Retrieved } & 10 & \text { February } & \text { 2021, from }\end{array}$ https://www.dhakatribune.com/business/2020/07/12/jute-sector-can-generate-more-employment-if-governm ent-provides-policy-support

Mirdha, R. (2018). Car brands fond of Bangladeshi jute. The Daily Star. Retrieved 10 February 2021, from https://www.thedailystar.net/business/car-brands-fond-bangladeshi-jute-1553884

Moazzem, K. G., \& Chowdhury, S. (2010). Restructuring of the Jute Manufacturing Sector of Bangladesh: Challenges and Policy Options. Working Paper of Center for Policy Dialogue, Dhaka. Retrieved 10 February 2021, from https://cpd.org.bd/wp-content/uploads/2013/03/Jute-paper-Final.pdf

Moazzem, K. G., Rahman, M. T., \& Sobhan, A. (2009). Jute Manufacturing Sector of Bangladesh: Challenges, Opportunities and Policy Options. CPD occasional paper No.78. Dhaka. Centre for Policy Dialogue (CPD). Retrieved 10 February 2021, from https://www.cpd.org.bd/pub_attach/op78.pdf

Molla, M. (2019). BJMC fund crunch cuts jute purchase. The Daily Star. Retrieved 10 February 2021, from https://www.thedailystar.net/frontpage/news/bangladesh-jute-mills-corporation-fund-crunch-cuts-jute-purch ase- 1711192

Parvez, S. (2018). Govt widens reach of jute packaging law. The Daily Star. Retrieved 10 February 2021, from https://www.thedailystar.net/news/business/advantages-of-using-jute-bags-in-bangladesh-government-wide ns-reach-1619488

Parvez, S. (2019_. BJMC burdened with losses. The Daily Star. Retrieved 10 February 2021, from https:/www.thedailystar.net/frontpage/bangladesh-jute-mills-corporation-burdened-with-losses-1743721

Rahman, M., \& Khaled, N. (2011). Global Market Opportunities in Export of Jute. Occasional Paper, Centre for Policy Dialogue, Dhaka. Retrieved 10 February 2021, from https://www.cpd.org.bd/pub_attach/op93.pdf

Sarkar, S., \& Sengupta, K. (2015). Comprehensive Technique for Jute Fibre Retting. International Journal of Bio-Resource And Stress Management, 6(1), 170. https://doi.org/10.5958/0976-4038.2015.00023.8 
Sheheli, S., \& Roy, B. (2015). Constraints and opportunities of raw jute production: a household level analysis in Bangladesh. Progressive Agriculture, 25, 38-46. https://doi.org/10.3329/pa.v25i0.24070

Textile Today. (2017). Indian Anti-Dumping Duty Affects Bangladesh's Jute Export. Retrieved 10 February 2021, from https:/www.textiletoday.com.bd/indian-anti-dumping-duty-affects-bangladeshs-jute-export/

Textile Today. (2017). Manufacturing of Regenerated Cellulose Fiber (Viscose) In Bangladesh Using Jute as A $\begin{array}{llllll}\text { Raw } & \text { Material. } & \text { Retrieved } & 10 & \text { February } & \text { 2021, from }\end{array}$ https://www.textiletoday.com.bd/manufacturing-regenerated-cellulose-fiber-viscose-bangladesh-using-jute-r aw-material/

The Daily Observer. (2017). BJMC a den of corruption, says Minister Mirza Azam. Retrieved 10 February 2021, from https://www.observerbd.com/details.php?id=61149

The Financial Express. (2018). Reviving Jute Industry. Retrieved 10 February 2021, from https://thefinancialexpress.com.bd/editorial/reviving-jute-industry-1520781904

The Financial Express. (2020). 21.55pc growth of export of jute, jute-made goods in July-Dec. Retrieved 10 February 2021 ,

from https:/www.thefinancialexpress.com.bd/trade/2155pc-growth-of-export-of-jute-jute-made-goods-in-july-de c-1578754361

The Financial Express. (2020). Export earnings from jute increase by $14 \mathrm{pc}$ in 10 months. Retrieved 10 February 2021 from https:/www.thefinancialexpress.com.bd/economy/bangladesh/export-earnings-from-jute-increase-by-14pc-i n-10-months-1590930564\#: :text=Export\%20earnings\%20from\%20jute\%20and,period\%20of\%20the \%20p revious\%20fiscal

The Financial Express. (2020). Govt to shut all state-owned jute mills. Retrieved 10 February 2021, from https://thefinancialexpress.com.bd/national/govt-to-shut-all-state-owned-jute-mills-1593695258

Tithi, N. (2019). The challenges in reviving our jute sector. The Daily Star. Retrieved 10 February 2021, from https://www.thedailystar.net/opinion/perspective/news/the-challenges-reviving-our-jute-sector-1750705

Uddin, M. J., Hossain, J., \& Hoque, A. (2014). Present Condition of Jute Sector in Bangladesh. Bangla Vision Foundation, 14(1). Retrieved 10 February 2021, from http://bv-f.org/VOL-14/08.\%20BV\%20Final.pdf

\section{Copyrights}

Copyright for this article is retained by the author(s), with first publication rights granted to the journal.

This is an open-access article distributed under the terms and conditions of the Creative Commons Attribution license (http://creativecommons.org/licenses/by/4.0/). 